CORRIGENDUM

\title{
Mapping cation entry in photoreceptors and inner retinal neurons during early degeneration in the $\mathrm{P} 23 \mathrm{H}-3$ rat retina- CORRIGENDUM
}

YUAN ZHU, STUTI MISTRA, LISA NIVISON-SMITH, MONICA L. ACOSTA, ERICA L. FLETCHER, AND MICHAEL KALLONIATIS

doi:10.1017/S0952523813000047, Published by Cambridge University Press 5 April 2013.

In the article by Zhu et al., published online 5th April 2013, Stuti Misra's name was incorrectly spelled as Stuti Mistra on the first page of this article.

\section{Reference}

ZHU, Y., et al. (2013). Mapping cation entry in photoreceptors and inner retinal neurons during early degeneration in the P23H-3 rat retina. Visual Neuroscience Published by Cambridge University Press, 5 April 2013. doi:10.1017/S0952523813000047 